\title{
Penerapan Literasi pada Anak Usia 5-6 Tahun Sebagai Upaya Persiapan Masuk Ke Jenjang SD/MI
}

\author{
Endang Purnomosari ${ }^{\circledR}{ }^{\bowtie}$, Cepi Safruddin Abdul Jabar ${ }^{2}$, Muthmainah ${ }^{1}$ \\ Pendidikan Anak Usia Dini, Universitas Negeri Yogyakarta, Indonesia(1) \\ Manajemen Pendidikan, Universitas Negeri Yogyakarta, Indonesia(2) \\ DOI: $10.31004 /$ obsesi.v6i4.2348
}

\begin{abstract}
Abstrak
Strategi guru merupakan unsur penting dalam proses pembelajaran. Mengenalkan konsep dasar literasi kepada anak usia dini sebagai bekal memasuki jenjang pendidikan selanjutnya, selain itu, anak juga dituntut paham tentang konsep literasi. Tujuan penelitian ini untuk mengetahui strategi guru untuk mengenalkan konsep dasar literasi pada anak kelompok B usia 5-6 tahun di TK Pertiwi Cawas IV sebagai persiapan memasuki SD/MI. Penelitian ini menggunakan metode kualitatif dengan pendekatan deskriptif. Teknik pengumpulan data menggunakan observasi, wawancara dan dokumentasi. Analisis data menggunakan trianggulasi teknik dan trianggulasi sumber. Hasil Penelitian menunjukan bahwa guru menggunakan beberapa strategi untuk mengenalkan konsep dasar literasi diantaranya strategi belajar langsung atau melalui bermain, melibatkan orang tua dalam kegiatan pembelajaran, bercerita, pemanfaatan media digital. Adapun faktor yang mempengaruhi guru untuk menggunakan strategi dalam mengenalkan konsep dasar literasi ialah karateristik peserta didik yang berbeda, kemampuan anak masih rendah, tuntutan orang tua dan adanya prasyarat untuk masuk SD/MI.
\end{abstract}

Kata Kunci: strategi guru; literasi; anak usia dini

\begin{abstract}
The teacher's strategy is an important element in the learning process. Introducing the basic concepts of literacy to early childhood as a provision for entering the next level of education, besides that, children are also required to understand the concept of literacy. The purpose of this study was to determine the teacher's strategy to introduce the basic concepts of literacy to children in group B aged 5-6 years in TK Pertiwi Cawas IV as preparation for entering SD/MI. This study uses a qualitative method with a descriptive approach. Data collection techniques using observation, interviews, and documentation. Data analysis used technique triangulation and source triangulation. The results showed that teachers used several strategies to introduce the basic concepts of literacy including direct learning strategies or through playing, involving parents in learning activities, telling stories, using digital media. The factors that influence teachers to use strategies in introducing the basic concepts of literacy are the different characteristics of students, children's abilities are still low, parental demands, and the prerequisites for entering SD/MI.
\end{abstract}

Keywords: teacher strategy; literacy; early childhood

Copyright (c) 2021 Endang Purnomosari, et al.

$\triangle$ Corresponding author :

Email Address : endangpurnomosari21@gmail.com (Universitas Negeri Yogyakarta, Indonesia) 
Received 30 October 2021, Accepted 24 February 2022, Published 25 February 2022

\section{PENDAHULUAN}

Pendidikan anak usia dini menentukan pendidikan selanjutnya. Sebagai jenjang paling dasar, Pendidikan Anak Usia Dini diharapkan menjadi fundamen bagi penyiapan peserta didik agar lebih siap dalam memasuki jenjang pendidikan lebih tinggi. Mengantarkan anak usia dini yang siap melanjutkan pendidikan tidak hanya terbatas pada kemampuan anak membaca, menulis, dan berhitung, tetapi juga dalam keseluruhan aspek perkembangan (Suminah et al., 2015). Menurut (Fauziah \& Rahman, 2021) Pendidikan anak pada dasarnya bertujuan untuk merangsang, membimbing, merawat dan memberikan kegiatan belajar yang akan menghasilkan kemampuan dan keterampilan anak agar berkembang maksimal. Pembinaan yang dilakukan adalah berupa pemberian stimulasi-stimulasi yang tepat pada setiap aspek perkembangan dan sesuai pola perkembangan masing-masing anak. Aspek yang dimaksud adalah aspek fisik motorik, kognitif, bahasa, sosial emosional, agama dan moral, serta seni. Pernyataan ini juga dikuatkan dengan pendapat dari (Fahmi et al., 2020) bahwa terdapat enam aspek yang dikembangan pada anak usia dini meliputi aspek pengembangan pembiasaan meliputi sosial, emosi, kemandirian, moral, dan nilai-nilai agama, serta pengembangan kemampuan dasar yang meliputi pengembangan bahasa, kognitif, dan fisik motorik.

Anak usia dini merupakan masa yang paling kritis dan cepat dalam memberikan stimulasi perkembangan anak (Zeng et al., 2017). Menurut Feinberg, usia dini merupakan periode sensitif untuk mendapatkan pengalaman belajar yang berkualitas (Cabell et al., 2019), misalnya keterampilan berbahasa dan literasi yang merupakan dasar untuk akuisisi bacaan anak pada tahap usia selanjutnya, dimana pada usia prasekolah, pengetahuan anak meluas dari waktu ke waktu (Cabell et al., 2013). Dengan demikian, pada usia dini sangat penting untuk mengidentifikasi pendidikan praktik dan kondisi yang memfasilitasi pertumbuhan keterampilan ini sebelum masuk taman kanak-kanak.

Menurut Baynham (dalam Marwiyati \& Hidayatulloh, 2018) pengertian literasi berdasarkan konteks penggunaanya diartikan sebagai integrasi keterampilan menyimak, berbicara, menulis, membaca, dan berpikir kritis. Menurut (Khomsiyatun, 2019) literasi mengacu pada kemampuan membaca. Sedangkan pada anak usia dini, literasi yang dikembangkan adalah kemampuan yang berkaitan dengan membaca, menulis, dan berhitung (Marwiyati \& Hidayatulloh, 2018). Pengertian tersebut didukung dengan pernyataan dalam Permendikbud no. 137 tahun 2014 (dalam Karima \& Kurniawati, 2020) dijelaskan bahwa pendidikan calistung pada anak usia dini hanya boleh dilakukan untuk pengenalan kemampuan membaca, menulis, dan berhitung pada anak. Literasi merupakan stimulasi yang kuat untuk mengembangkan kemampuan membaca, menulis, dan berhitung pada anak (Dickinson et al., 2012; Hidayat et al., 2021).

Pengenalan konsep dasar literasi merupakan salah satu upaya yang dilakukan untuk mengembangkan kemampuan kognitif dan bahasa anak yang meliputi pengenalan konsep membaca, menulis dan berhitung, sehingga anak tidak mengalami kesulitan untuk menyesuaikan yang diterapkan di sekolah lanjutan, yaitu Sekolah Dasar atau Madrasah Ibtidaiyah (Fahmi et al., 2020). Pernyataan ini didukung dengan pendapat dari Hurlock (dalam Marwiyati \& Hidayatulloh, 2018) bahwa kemampuan literasi anak mempengaruhi perkembangan sosial, emosi, dan perkembangan kognitifnya. Dengan demikian, pengenalan konsep literasi sejak dini dapat mempengaruhi perkembangan anak dari berbagai domain perkembangan.

Menurut World's Most Literate Nations Ranked tahun 2016, dari 61 Negara, budaya literasi Indonesia berada pada posisi ke-60. Data ini menunjukkan bahwa literasi Indonesia masih tergolong rendah, khususnya di kalangan anak-anak, yaitu sekitar $99 \%$ yang tidak suka membaca dan $1 \%$ menyatakan suka membaca, anak lebih menyukai game online (Sumaryanti, 2018). Keadaan tersebut tentu membutuhkan perhatian utama bagi para pendidik yang merupakan agen perubahan yang utama dalam Pendidikan. Menanamkan budaya literasi 
tidaklah mudah, membutuhkan proses yang panjang. Budaya ini dapat dimulai dari lingkungan keluarga, sekolah dan masyarakat. Menurut (Meliantina, 2019) dalam pelaksanaan program literasi sekolah, semua guru memiliki peran masing-masing dalam kaitannya dengan kegiatan literasi.

Dari hal yang di sampaikan diatas maka tema penelitian yang diangkat dalam penelitian ini ialah tentang strategi guru mengenalkan konsep literasi di TK Pertiwi Cawas IV untuk mepersiapkan masuk SD/MI. Tujuan penelitian ini mendeskripsikan strategi guru mengenalkan konsep membaca, menulis dan berhitung pada anak usia dini sebagai Upaya persiapan masuk SD/MI. Mengetahui faktor yang mempengaruhi guru menggunakan strategi dalam mengenalkan konsep literasi pada anak sebagai upaya persiapan masuk SD/MI. Adapun Manfaat yang didapatkan dari penelitian ini yaitu, agar guru atau pendidik memahami tentang strategi pembelajaran dan konsep mengenalkan pembelajaran membaca, menulis dan berhitung dengan memperhatikan kegiatan pembelajaran yang memuat unsur belajar seraya bermain atau bermain seraya belajar, serta sesuai dengan kebutuhan dan perkembangan anak. Selain itu, agar dapat memahami faktor yang dapat mempengaruhi dalam mengenalkan konsep literasi pada anak.

\section{METODOLOGI}

Metode yang digunakan dalam penelitian ini adalah metode kualitatif pendekatan deskriptif artinya hasil dari penelitian ini disajikan dengan memaparkan data yang diperoleh dari hasil identifikasi tentang strategi guru mengenalkan konsep literasi di PAUD untuk mempersiapkan masuk SD/MI pada anak kelompok B usia 5-6 tahun di TK Pertiwi Cawas IV. Teknik pengumpulan data yang digunakan yaitu observasi, wawancara dan dokumentasi. Alat pengumpul data berupa observasi, wawancara, dan dokumentasi. Observasi dan wawancara digunakan untuk mengetahui strategi yang digunakan guru dalam mengenalkan konsep literasi pada anak. Dokumentasi untuk mengetahui proses pembelajaran yang dilaksanakan pada saat guru mengenalkan konsep literasi pada anak meliputi unsur membaca, menulis dan berhitung.

Tehnik analisis data yang digunakan untuk menggambarkan tentang hasil penelitian dilakukan secara terstruktur menggunakan empat konsep cara yaitu pengumpulan data, reduksi data, penyajian data dan penarikan kesimpulan. Adapun Tehnik Pemeriksaan keabsahan data berdasarkan kriteria kepercayaan, maka yang digunakan adalah trianggulasi, yaitu tehnik pemeriksaan keabsahan data yang memanfaatkan sesuatu di luar data itu untuk keperluan pengecekan atau sebagai pembanding terhadap data itu. Triangulasi yang akan digunakan peneliti adalah triangulasi sumber yaitu membandingkan dan mengecek baik derajat kepercayaan suatu informasi yang diperoleh melalui alat yang berbeda. Hal ini dapat dicapai dengan cara: (1) membandingkan data hasil observasi dengan wawancara, (2) membandingkan subyek dan informan, (3) membandingkan hasil wawancara dengan dokumen yang berkaitan.

Gambar 1 disajikan langkah analisis data penelitian tentang strategi guru mengenalkan konsep literasi di PAUD untuk mempersiapkan masuk SD/MI.

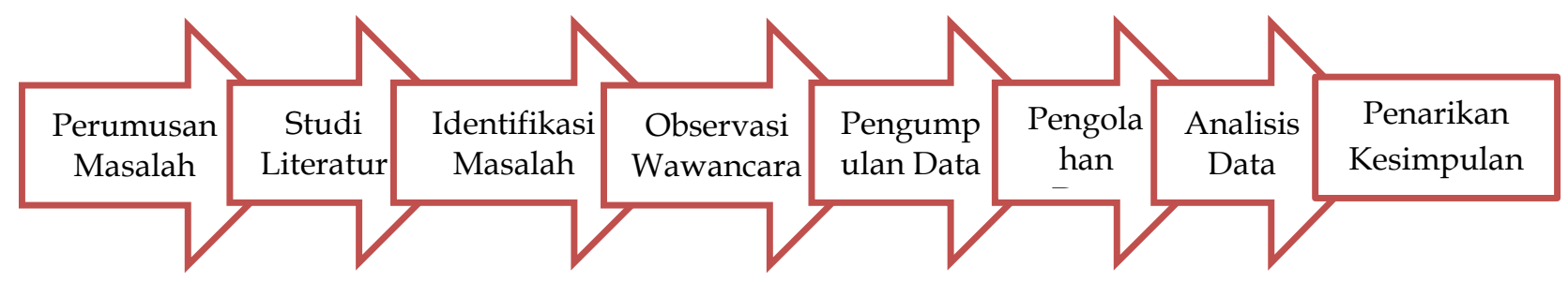

Gambar 1 Bagan alur penelitian 


\section{HASIL DAN PEMBAHASAN}

Guru sebagai pusat pembelajaran bagi anak, tidak hanya memiliki kemampuan dalam mengajar akan tetapi harus memiliki daya kreativitas yang tinggi untuk menarik minat anak dalam belajar terutama pada pembelajaran membaca, menulis dan berhitung yang biasa dikenal dengan literasi, sebagaimana yang dilaksanakan di TK Pertiwi Cawas IV, guru merasa penting untuk mengembangkan kreativitasnya dalam membuat dan mempersiapkan kegiatan pembelajaran agar dapat memenuhi kebutuhan anak dalam pembelajaran dan tentunya juga menarik minat anak untuk belajar terutama dalam mengenalkan konsep literasi pada anak, guru juga mempersiapkan strategi khusus agar anak dapat dengan mudah memahami dan mengenal bentuk huruf dan bilangan, bunyi huruf dan tatacara menjumlah bilangan. ada beberapa media yang dipersiapkan guru untuk menunjang pembelajaran diantaranya kartu huruf dan angka, lembar kerja anak, papan tulis, media cerita (kain celemek, papan flanel, dan boneka jari) yang dapat digunakan guru untuk memberikan contoh kepada anak. selain itu, guru juga menggunakan metode-metode yang dapat mempermudah anak dalam mengingat dan menghafal huruf dan angka diantaranya dengan menggunakan metode bernyanyi, bercerita dan karyawisata, dan bermain peran.

Untuk penelitian kualitatif, bagian hasil memuat bagian-bagian rinci dalam bentuk sub topik-sub topik yang berkaitan langsung dengan fokus penelitian dan kategori-kategori. Pembahasan dalam artikel bertujuan untuk: (1) menjawab rumusan masalah dan pertanyaanpertanyaan penelitian; (2) menunjukkan bagaimana temuan-temuan itu diperoleh; (3) menginterpretasi/menafsirkan temuan-temuan; (4) mengaitkan hasil temuan penelitian dengan struktur pengetahuan yang telah mapan; dan (5) memunculkan teori-teori baru atau modifikasi teori yang telah ada.

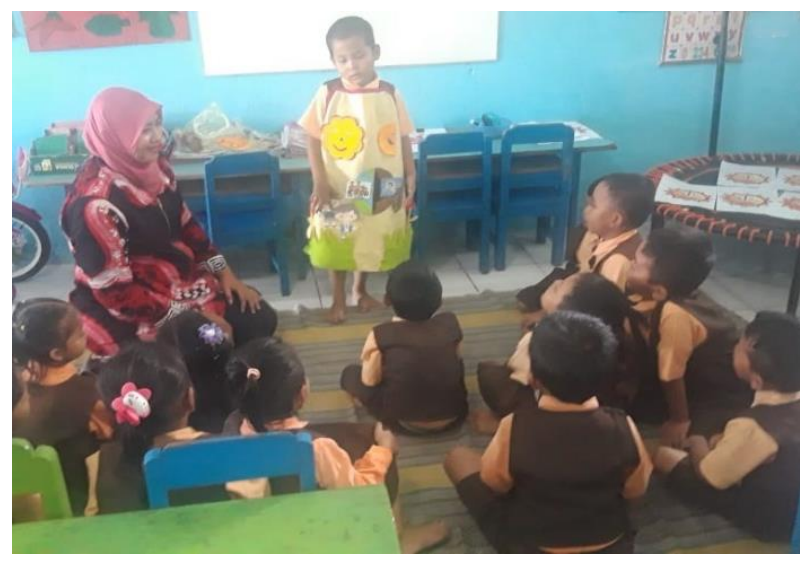

Gambar 1. Pembelajaran secara langsung/penyampaian gagasan anak

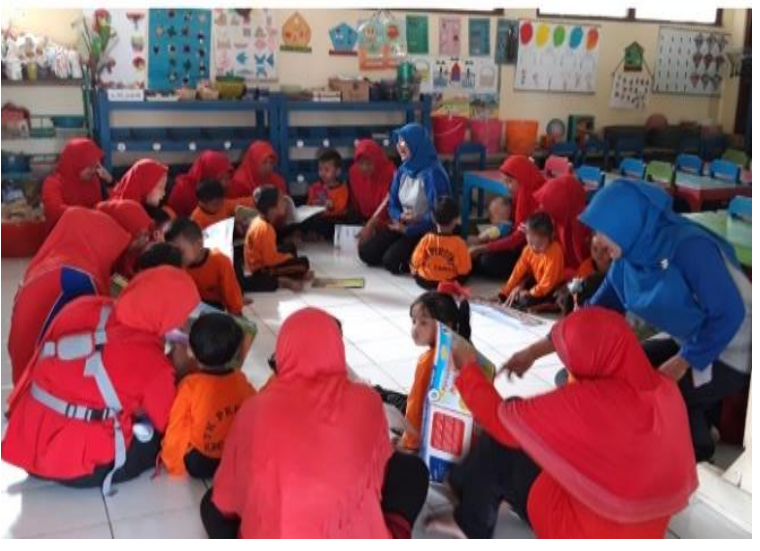

Gambar 2. Proses pembelajaran calistung melibatkan orang tua

Sebagaimana hasil observasi yang dilakukan di TK Pertiwi Cawas IV, dapat diketahui bahwa kegiatan pembelajaran dilaksanakan berdasarkan pada Rencana Pelaksanaan Pembelajaran (RPP) yang telah dibuat dan sudah dipersiapkan guru setiap hari. kegiatan pembelajaran mencakup pembiasaan-pembiasaan untuk mengembangkan karakter anak, selain itu pada kegiatan inti guru menyusun kegiatan-kegiatan yang menekankan pada beberapa aspek perkembangan seperti bahasa kaitannya dengan membaca atau mengenal bunyi huruf, aspek kognitif termasuk di dalamnya mengenal huruf, dan mengenal angka, aspek sosial dan emosional, agama, motorik dan seni. Dalam proses kegiatan pembelajaran guru juga menggunakan media, adapun media yang digunakan untuk mengenalkan konsep dasar literasi pada anak yaitu, papan tulis sebagai pembuka dan sebagai media mengenalkan hari, tanggal, bulan dan tahun,dalam pengenalannya dilakukan dengan bernyanyi juga sehingga anak akan mudah mengingatnya. Media papan tulis juga digunakan guru sebagai 
media untuk mengenalkan langsung cara membuat huruf, atau mengenal bentuk huruf dan angka, selain itu ada kartu bergambar yang digunakan untuk mengenal bunyi huruf dan bacaan. Berikut beberapa strategi yang digunakan guru untuk mengenalkan konsep dasar literasi pada anak usia dini.

\section{Pembelajaran Langsung}

Pembelajaran langsung atau biasa disebut strategi belajar melalui bermain merupakan strategi yang menyajikan materi pembelajaran secara langsung kepada anak, dan anak diberikan kesempatan untuk melakukan sendiri, atau bermain sendiri dengan menggunakan bermacam-macam biji-bijian yang disusun menjadi bentuk huruf, puzzle huruf/angka, kartu gambar, kartu angka, dsb. Adapun peran guru memfasilitasi belajar anak agar mencapai tujuan yanga telah direncanakan (Nuraeni, 2014). Strategi berajar langsung atau bermain tidak hanya dilaksanakan di dalam ruangan (Indoor) tetapi juga di luar ruangan (Outdoor). pada saat bermain di luar ruangan anak bisa lebih berkreasi melalui bahan-bahan yang disediakan oleh alam. Bermain di luar atau outdoor dapat menciptakan kesenangan pada anak dan dapat membantu pertumbuhan dan perkembangan anak, karena dilingkungan outdoor tersedia lingkungan dan bahan bermain yang disediakan oleh alam dan anak dapat melihat setiap benda-benda yang ada disekitarnya (Susilowati, 2014). Belajar langsung maupun belajar melalu bermain dilaksanakan sebagai upaya untuk mengenalkan konsep dasar literasi, karena media yang digunakan anak untuk kegiatan bermain terdapat unsur-unsur literasi, misalnya media balok huruf, Sofiyani mengemukakan bahwa balok huruf merupakan media atau alat permainan yang berbentuk kotak atau kubus kecil yang terdiri dari 6 sisi dan setiap sisinya diberi kata dan gambar yang dapat digunakan untuk permainan mengenal huruf dan kata (Andiyani, 2015).

Strategi ini dapat digunakan oleh guru sebagai salah satu cara untuk mengenalkan konsep dasar literasi pada anak, yang mana anak secara tidak langsung diajak untuk mengenal konsep membaca, menulis dan berhitung pada saat melakukan kegiatan bermain. Sebagaimana hasil wawancara dengan guru di TK Pertiwi Cawas IV diperoleh informasi bahwa konsep dasar literasi yang dikenalkan kepada anak, di awali dengan mengenalkan konsep membaca, menulis dan berhitung. strategi yang digunakan dalam upaya mengenalkan kosep dasar literasi ini salah satunya dengan kegiatan bermain, pada saat kegiatan bermain anak akan disajikan beberapa media yang di dalamnya mengandung unsur literasi, misal menggunakan media puzzle angka/huruf, yang mana anak di ajak untuk menyusun huruf dan mengenal bentuk huruf dan bunyi huruf, jadi pada kegiatan ini selain bermain anak juga di ajak untuk mengembangkan pengetahuannya, jadi disini posisi guru sebagai pemberi stimulasi kepada anak, guru sesekali memberikan pertanyaan kepada anak terkait bunyi huruf atau mencari huruf yang disebutkan oleh guru.

\section{Melibatkan Orang Tua Dalam Kegiatan Literasi}

Melibatkan orang tua dalam kegiatan pembelajaran yang dilaksanakan di dalam kelas atau di luar kelas. keterlibatan orang tua dalam kegiatan di sekolah mengarah kepada adanya hubungan kerjasama antara guru dan orang tua guna meningkatkan perkembangan anak. Strategi ini tidak hanya terfokus pada mengenalkan konsep dasar literasi saja akan tetapi mencakup beberapa aspek yang dapat membantu anak untuk berkembang potensi yang ada dalam dirinya baik secara fisik, sosial maupun intelektualnya. mengenalkan konsep dasar literasi pada anak usia dini dini melalui keterlibatan orang tua dapat dilakukan dengan memberikan kegiatan-kegiatan membacakan buku cerita kepada anak, kemudian permainan yang melibatkan orang tua untuk menstimulasi interaksi verbal anak, memperkaya kosa kata, mendorong pembicaraan mengenai buku, melatih pengucapan kata, dan mengembangkan pengetahuan mengenai bahan-bahan cetak (seperti mengenalkan huruf-huruf, membiasakan anak dengan mekanisme dan tujuan dasar dari membaca sebuah bacaan) (Karima \& Kurniawati, 2020). 
Upaya mengenalkan konsep literasi pada anak melibatkan orang tua dalam kegiatan di sekolah merupakan salah satu strategi yang digunakan guru. Sebagaimana informasi yang didapatkan dari hasil wawancara di TK Pertiwi Cawas IV, guru, orang tua bersama anak membangun kerjasama agar setiap kegiatan dapat dilakukan oleh anak, salah satu kegiatan yang dilaksanakan guru terkait dengan keterlibatan orang tua dilakukan dengan pada harihari tertentu terkait puncak tema, kegiatan awal yang dilakukan bersama adalah kegiatan gerak dan lagu yang dilakukan bersama antara anak dan orang tua serta guru, kemudian kegiatan inti yaitu kegiatan orang tua dengan membacakan buku, dimana buku yang dipilih oleh anak yang diambil dari pojok buku (perpustakaan sekolah). Setelah kegiatan dilakukan tentunya ada pertanyaan-pertanyaan yang dilontarkan orang tua terhadap anak terkait dengan buku yang dibacakan dan tentunya saling berinteraksi antara anak dan orang tua, guru senantiasa memotivasi dan memberikan fasilitas atas kegiatan yang dilakukan. Kegiatan akhir dilakukan dengan recalling dan pemberian hadiah kepada kelompok ibu dan anak yang berhasil dan berani menceritakan apa kegiatan yang telah dilakukan pada hari ini. Hal itu sebagai wujud apresiasi dan dapat memberikan dorongan agar anak yang lain mau untuk melakukannya dilain hari. itulah strategi yang digunakan agar anak dapat belajar tentang konsep dasar literasi dari beberapa kegiatan yang dilakukan di sekolah.

\section{Bercerita}

Bercerita adalah suatu kegiatan yang dilakukan seseorang secara lisan kepada orang lain dengan alat tentang apa yang harus disampaikan dalam bentuk pesan, informasi, atau hanya sebuah dongeng yang dikemas dalam bentuk cerita yang dapat didengarkan dengan rasa menyenangkan. Pada pendidikan anak usia dini, bercerita adalah salah satu metode pengembangan bahasa yang dapat mengembangkan beberapa aspek fisik maupun psikis anak sesuai dengan tahapannya. Salah satunya yaitu kemampuan berbicara.

Bercerita adalah menyampaikan sesuatu yang berisi tentang suatu kejadian yang disampaikan melalui media, dengan tujuan memberikan pengetahuan dan pesan dalam cerita tersebut menurut Bachir (Fauziah \& Rahman, 2021). Bercerita adalah menyampaikan sesuatu yang berisi perbuatan pengalaman atau sesuatu kejadian yang nyata maupun buatan belaka. Metode bercerita merupakan salah satu proses belajar bagi anak TK dengan menyajikan cerita kepada anak. Bercerita menanamkan kemampuan berpikir dan memberikan peluang bagi anak untuk belajar menelaah kejadian-kejadian disekelilingnya. Berbagai macam cerita, diungkapkan dengan perasaan yang sesuai dengan apa yang dialami, dirasakan, dan dilihat berdasarkan pengalaman yang diperoleh. Menurut (Fauziah \& Rahman, 2021) menyatakan bahwa cerita merupakan salah satu dari keterampilan berbicara yang bertujuan untuk memberikan informasi. Dengan bercerita seseorang dapat menyampaikan suatu informasi kepada orang lain. Hal ini juga berlaku pada Anak Usia Dini (AUD) dengan adanya metode bercerita mereka secara tidak sadar pasti melakukan proses bercerita ini kepada teman sebaya, kepada keluarga, maupun kepada guru. Sebagaimana hasil wawancara dengan guru di TK Pertiwi Cawas IV, sebagai berikut:

"kami menggunakan strategi bercerita sesuai tema dan subtema pembelajaran setiap hari. Kegiatan bercerita terkadang dilaksanakan di awal maupun di akhir pembelajaran. Kami menyesuaikan sesuai kondisi anak-anak. Biasanya kami memepersilahkan anak atau memberikan pertanyaan kepada anak tentang pengalaman yang didapatkan ketika persiapan sekolah sampai menuju ke sekolah. Selain itu, kami juga mempersilahkan kepada anak untuk menceritakan pengalaman belajarnya pada hari itu (recalling). Kegiatan ini bertujuan agar anak mampu mengungkapkan gagasan yang ada dalam pikiran anak, dan melatih anak berkomunikasi dan merangkai kata atau kalimat menjadi sebuah cerita.

\section{Pemanfaatan Media Digital}

Tanggap secara digital jauh melebihi keterampilan membaca, menulis, mendengar dan berbicara. Dengan media dan teknologi digital saat ini, seseorang dapat membuat, bekerja, 
berbagi, bersosialisasi, meneliti, bermain, berkolaborasi, berkomunikasi dan belajar. Teknologi dan perkembangan baru di media telah mengubah cara individu, kelompok, dan masyarakat berkomunikasi, belajar dan bekerja (Meyers et al., 2013). Pemanfaatan dan penggunaan perangkat pembelajaran IT yang murah dan mudah dari aplikasi di playstore dan youtube HP android atau laptop jauh lebih menarik minat belajar literasi anak di PAUD, pembelajaran melalui aplikasi play store pada hand phone android untuk memperoleh free books dan men-download berbagai materi atau media pembelajaran dengan youtube. Penelitian digital literasi yang dapat dijadikan acuan yakni penelitian yang mengeksplorasi penggunaan YouTube di ruang kelas terhadap sejumlah kelompok fokus yang menyoroti sejumlah masalah seputar lingkungan belajar informal yang independen. Penelitian ini mengungkap bagaimana para siswa berinteraksi satu sama lain di ruang-ruang informal dan peran yang dimainkan konten video YouTube dalam pembentukan komunitas dan mendukung pembelajaran sebaya dalam format informal. Sifat ruang belajar informal adalah bahwa fokus mereka bukan hanya pada pendidikan, tetapi juga hiburan mengarah pada variasi dalam kualitas, keandalan dan kesesuaian konten (Tan, 2013). Meski literasi digital sering didefinisikan secara sempit yakni hanya sebagai masalah keterampilan teknis, namun tak dapat dipungkiri bahwa pendidikan tentang media harus dilihat sebagai prasyarat yang sangat diperlukan untuk pendidikan melalui media (Buckingham, 2015). Sebagaimana hasil wawancara dengan guru di TK Pertiwi Cawas IV, sebagai berikut:

"Kami menggunakan strategi pemanfaatan media digital dalam pembelajaran di TK Pertiwi Cawas IV, terlebih pada masa pandemi covid-19. Tujuannya untuk mengenalkan anak pembelajaran yang akan disampaikan kepada anak seperti, pembuatan PPT, cerita dengan video dan aplikasi game lainnya. Strategi ini sangat optimal pelaksanaanya dimana terlihat anak-anak sangat antusias dan selalu mengikuti kegiatan dengan baik. Strategi ini bila pelaksanaannya di masa pandemic, maka orangtua menjadi pendamping utama dalam pelaksanaannya, dan sebaliknya apabila dilaksanakan di sekolah, guru menjadi pendamping utama dan terkadang Sebagian orangtua ikut serta dalam pendampingan di sekolah, sebagaimana terlihat pada dokumentasi penelitian.".

\section{Faktor-faktor yang Mempengaruhi Guru dalam Penerapkan Literasi pada Anak Karakteristik peserta didik}

Peserta didik adalah orang yang belajar. Karakteristik peserta didik adalah keunikan yang dimiliki oleh setiap peserta didik dalam proses belajarnya. Menurut Sadulloh dalam (Nurhamida, 2018) mengatakan peserta didik merupakan seseorang yang sedang berkembang, memiliki potensi tertentu, dan dengan bantuan pendidik ia mengembangkan potensinya tersebut secara optimal. Karakteristik pertumbuhan dan perkembangan anak tergantung kualitas stimulasi orangtua dan guru (Idria, 2016). Apabila stimulasi diberikan kepada anak sedini mungkin dan terus menerus berkelanjutan maka akan bermanfaat bagi proses kesiapan dan kematangan anak sehingga berdampak pada keberhasilan anak pada Pendidikan selanjutnya (Meilanie, 2021). Stimulasi dini yang dilakukan oleh orang tua dan guru dapat menumbuhkan kepercayaan diri dan kemandirian pada anak serta optimalnya capaian perkembangan anak menuju pendidikan selanjutnya (Muna, 2017). Sebaliknya jika pola stimulasi yang diterapkan tidak tepat akan berdampak pula pada perkembngan anak dan tentunya mempengaruhi perkembangan pendidikan anak pada Pendidikan selanjutnya (Hasanah, 2020).

Karakteristik merupakan salah satu faktor yang dapat mempengaruhi dalam proses mengenalkan konsep literasi, karena pada masa usia dini anak berada dimasa perkembangan yang sangat pesat, secara umum karakteristik anak usia dini sangat berbeda dengan orang dewasa, oleh karena itu, guru juga harus memahami cara yang tepat untuk memahami setiap anak yang memiliki karakteristik berbeda pula. Karakteristik anak usia dini yang harus dipahami oleh guru atau orang tua yaitu: 1) anak memiliki rasa ingin tahu yang besar, 2) anak merupakan pribadi yang unik, 3) anak suka berfantasi dan berimajinasi, 4) masa usia dini 
merupakan masa potensial untuk belajar, 5) anak memiliki sikap egosentris, 6) anak memiliki rentan daya konsentrasi yang pendek, 7) anak merupakan bagian dari mahluk sosial. Sebagaimana hasil wawancara dengan guru di TK Pertiwi Cawas IV, sebagai berikut:

"Bahwa pada awal pembelajaran, terlebih dahulu kami/para guru memahami karakteristik anak, termasuk potensi-potensi yang dimiliki anak, mengingat anak usia dini berada pada fase perkembangan yang sangat kritis dan menentukan pendidikan selanjutnya. Tujuannya agar guru memahami karakteristik anak, sehingga segala potensi yang dimiliki akan, semaksimal mungkin akan diberikan stimulasi sesuai kemampuan mereka"

\section{Rendahnya Kemampuan Peserta Didik}

Kemampuan Peserta Didik Masih Rendah Peserta didik adalah anggota masyarakat yang berusaha mengembangkan potensi diri melalui proses pembelajaran yang tersedia pada jalur, jenjang dan jenis pendidikan tertentu. (Undang-undang Sistem Pendidikan Nasional No 20 Tahun 2003). Selain itu, terdapat dua hal yang perlu dipahami oleh guru terhdap peserta didik yaitu keunggulan dan kekurangannya. Jadi pada dasarnya guru harus memahami peserta didik dari segala aspek diantaranya aspek tahap perkembangannya, kemampuan, keunggulan serta kekurangannya, faktor penghambat dan faktor pendukung yang dapat mempengaruhinya (Mundia \& Heru, 2020). Kemampuan anak memahami pembelajaran erat hubungannya dengan kemampuan proses berpikir anak atau kemampuan kognitif anak. Kemampuan kognitif merupakan suatu proses berfikir, yang diukur dari kemampuan anak dalam menghubungkan, menilai suatu kejadian atau peristiwa, kemampuan anak juga dapat dilihat pada saat anak bermain, diantaranya mengelompokkan benda yang memiliki persamaan warna, bentuk, dan ukuran, mencocokkan lingkaran, segitiga, dan segiempat serta mengenali dan menghitung angka 1 sampai 20 (Rahmat, 2017). Rendahnya kemampuan peserta didik ini juga disebabkan oleh beberapa faktor seperti lingkungan, psikologis, oleh karena itu, tetapi peran peserta didik tidak hanya dapat memperkuat dan mendukung proses pembelajaran akan tetapi peran peserta didik juga dapat memperlemah pencapaian tujuan pembelajaran. Sebagaimana hasil wawancara dengan guru di TK Pertiwi Cawas IV, sebagai berikut:

"Bahwa peserta didik sebagian besar memiliki kemampuan yang masih rendah, terlihat anak masih banyak yang belum bisa menulis angka dan huruf, masih ragu dalam menyampaikan sesuatu, masih malu-malu, dan masih membutuhkan bantuan dari guru maupun orangtua. Hal itu lah yang menuntut guru harus lebih kreatif dalam mempersiapkan baik stratetegi, media maupun materi pembelajaran agar anak yang memiliki kemampuan rendah dapat memahami dan mengikuti pembelajaran dengan baik sehingga dapat tercapai tujuan dari pendidikan".

\section{Harapan Orang Tua}

Mengenalkan konsep literasi pada anak usia dini, yang di dalamnya termasuk kemampuan membaca, menulis dan berhitung, merupakan fenomen yang saat ini hangat diperbincangkan, karena sebagian besar orang tua memiliki tujuan untuk memasukan anaknya ke lembaga PAUD agar memiliki kemampuan membaca, menulis dan berhitung, karena orang tua mengkhawatirkan anaknya terhalang masuk sekolah lanjutan baik Sekolah Dasar (SD) maupun Madrasah Ibtidaiyah (MI), diakibatkan tidak mampu membaca, menulis, dan berhitung. Harapan yang diberikan orang tua terhadap anak nya merupakan wujud perhatian dan tanggung jawab orang tua kepada anak. Sebagaimana peran orang tua sebagai fasilitator terhadap pendidikan anak. Orang tua dapat menjadi fasilitator dan motivator dalam pendidikan anak, termasuk menentukan berbagai cara untuk mendapatkan fasilitas yang dapat menunjang program belajar anak, karena peran orang tua juga dapat mempengaruhi hasil belajar anak, fasilitas yang dapat disediakan orang tua diantaranya berkenaan dengan penyediaan buku-buku ajar yang dibutuhkan peserta didik, demikian juga dengan fasilitas lainnya, seperti alat-alat tulis, tempat belajar, dan lain-lain (Umar, 2020). Sebagaimana hasil 
wawancara dengan beberapa orangtua peserta didik di TK Pertiwi Cawas IV yang menjadi alasan utama mereka agar anak mereka bisa calistung sejak TK, sebagai berikut:

"saya berharap ketika anak saya lulus dari TK, anak mampu menguasai keterampilan membaca, menulis dan berhitung. Karena kami mendengar isu-isu bahwa agar anak bisa masuk di sekolah-sekolah favorit haru memiliki keterampilan calistung".

Hasil wawancara lain dari orangtua peserta didik, adalah:

"Saya berharap anak saya itu sebisa mungkin bisa membaca dan menulis setelah lulus dari TK. Karena dengan itu, kami bisa mengetahui bahwa anak kami tergolong anak yang pintar karena sebelum masuk sekolah dasar, anak sudah memiliki keterampilan tersebut".

\section{SIMPULAN}

Mengenalkan konsep dasar literasi pada anak usia dini di lembaga PAUD khususnya di TK Pertiwi Cawas IV, harus merujuk kepada indikator perkembangan anak. Strategi yang digunakan guru diantaranya, pembelajaran langsung, atau belajar melalui bermain, melibatkan orang tua dalam kegiatan bermain dan belajar, bercerita atau mendongeng, pemanfaatan media digital dapat dijadikan kontribusi dalam mengenalkan konsep dasar literasi pada anak. Adapun faktor-faktor yang mengharuskan guru menggunakan strategi dalam mengajar ialah perbedaan karakteristik anak, kemampuan anak masih rendah, dan harapan orang tua yang menginginkan anaknya memahami konsep literasi pada saat lulus dijenjang PAUD.

\section{UCAPAN TERIMA KASIH}

Terimakasih penulis ucapkan kepada guru, Orang tua dan anak TK Pertiwi Cawas IV, telah berpartisipasi aktif membantu dalam proses wawancara dan saat peneliti melakukan observasi. Ucapan terimakasih juga kepada dewan editor dan redaksi Jurnal Obsesi yang telah berkenan untuk menerbitkan artikel ini.

\section{DAFTAR PUSTAKA}

Buckingham, D. (2015). Defining Digital Literacy: What do young people need to know about digital media? Medienbildung in Neuen Kulturräumen, 59-71. https://doi.org/10.1007/978-3-531-92133-4_4

Cabell, S. Q., Justice, L. M., Logan, J. A. R., \& Konold, T. R. (2013). Emergent literacy profiles among prekindergarten children from low-SES backgrounds: Longitudinal considerations. Early Childhood Research Quarterly, 28(3), 608-620. https://doi.org/10.1016/j.ecresq.2013.03.007

Cabell, S. Q., Zucker, T. A., DeCoster, J., Melo, C., Forston, L., \& Hamre, B. (2019). Prekindergarten Interactive Book Reading Quality and Children's Language and Literacy Development: Classroom Organization as a Moderator. Early Education and Development, 30(1), 1-18. https:// doi.org/10.1080/10409289.2018.1514845

Dickinson, D. K., Griffith, J. A., Golinkoff, R. M., \& Hirsh-Pasek, K. (2012). How Reading Books Fosters Language Development around the World. Child Development Research, 2012, 1-15. https:// doi.org/10.1155/2012/602807

Fahmi, F., Syabrina, M., Sulistyowati, S., \& Saudah, S. (2020). Strategi Guru Mengenalkan Konsep Dasar Literasi di PAUD Sebagai Persiapan Masuk SD/MI. Jurnal Obsesi : Jurnal Pendidikan Anak Usia Dini, 5(1), 931-940. https://doi.org/10.31004/obsesi.v5i1.673

Fauziah, F., \& Rahman, T. (2021). Meningkatkan Perkembangan Bahasa Anak Usia Dini Melalui Metode Bercerita. J-SANAK: Jurnal Kajian Anak, 2(2), 1-23. https:// doi.org/10.24127/j-sanak.v2i02.870

Hasanah, N. (2020). Analisis Pola Asuh Orang Tua terhadap Keterlambatan Bicara pada Anak Usia Dini. Jurnal Obsesi: Jurnal Pendidikan Anak Usia Dini, 4(2), 913-922. https://doi.org/10.31004/obsesi.v4i2.456 
Hidayat, L. F., Bayu, A., Nandiyanto, D., \& Kurniawan, T. (2021). The Literacy Habituation to Grow Early Childhood Language Skills Through Picture Story Books in Early Childhood Education. Jurnal Abdimas Kartika Wijayakusuma, 2, 115-120. https:// doi.org/10.26874/jakw.v2i2.134

Idria, M. H. (2016). Karakteristik Anak Usia Dini. Permata, 37-43.

Karima, R., \& Kurniawati, F. (2020). Kegiatan Literasi Awal Orang Tua pada Anak Usia Dini. Al-Athfal: Jurnal Pendidikan Anak, 6(1), 69-80. https://doi.org/10.14421/alathfal.2020.61-06

Khomsiyatun, U. (2019). Pola Pengembangan Literasi Bahasa Pada Anak Studi Kasus Di PAUD Wadas Kelir. JUrnal Metabasa, 1(2), 29-34. https:// doi.org/10.24235/equalita.v1i1.5160

Marwiyati, S., \& Hidayatulloh, M. A. (2018). Peran "Cakruk Baca Bergerak" Dalam Pengembangan Literasi Anak Usia Dini. AWLADY : Jurnal Pendidikan Anak, 4(2), 61. https:// doi.org/10.24235/awlady.v4i2.3236

Meilanie, R. S. M. (2021). Survei Kemampuan Guru dan Orangtua dalam Stimulasi Dini Sensori pada Anak Usia Dini. Jurnal Obsesi : Jurnal Pendidikan Anak Usia Dini, 5(1), 958-964. https://doi.org/10.31004/obsesi.v5i1.741

Meliantina. (2019). Menerapkan budaya literasi guru sekolah dalam upaya meningkatkan pendidikan di era industri 4.0. Muróbbî: Jurnal Ilmu Pendidikan, 3(2), 120-139.

Meyers, E. M., Erickson, I., \& Small, R. V. (2013). Digital literacy and informal learning environments: An introduction. Learning, Media and Technology, 38(4), 355-367. https:// doi.org/10.1080/17439884.2013.783597

Muna, F. A. N. (2017). Hasil pelaksanaan program stimulasi motorik kasar anak usia 2-3 tahun di TPA Assakinah Sengkaling Malang. 483-494.

Mundia, K., \& Heru, S. (2020). Kompetensi Pedagogik Guru dalam Melaksanakan Penilaian Pembelajaran Anak Usia Dini. Jurnal Obsesi : Jurnal Pendidikan Anak Usia Dini, 4(2), 900-912. https://doi.org/10.31004/obsesi.v4i2.478

Nuraeni. (2014). Stretegi Pembelajaran Anak Usia Dini. Prisma Sains : Jurnal Pengkajian Ilmu Dan Pembelajaran Matematika Dan IPA IKIP Mataram, 2(2), 143-153. https:// doi.org/10.33394/j-ps.v2i2.1069

Nurhamida, I. (2018). Problematika Kompetensi Pedagogik Guru Terhadap Karakteristik Peserta Didik. Jurnal Teori Dan Praksis Pembelajaran IPS, 3(1), 27-38. https:// doi.org/10.17977/um022v3i12018p027

Rahmat, F. (2017). Kontribusi Permainan Konstruktivis (Media Balok) Dengan Peningkatan Kemampuan Kognitif. JPUD - Jurnal Pendidikan Usia Dini, 11(2), 238-251. https:// doi.org/10.21009/JPUD.112.04

Sumaryanti, L. (2018). Membudayakan Literasi Pada Anak Usia Dini Dengan Metode Mendongeng. AL-ASASIYYA: Journal Of Basic Education, 3(1), 117. https://doi.org/10.24269/ajbe.v3i1.1332

Suminah, E., Siantayani, Y., Paramitha, D., Ritayanti, U., \& Nugraha, A. (2015). Pedoman Penilaian Pembelajaran Pendidikan Anak Usia Dini. In Direktorat Pembinaan Pendidikan Anak Usia Dini.

Susilowati, R. (2014). Strategi Belajar Out Door Bagi Anak PAUD. Thufula, 2(1), 65-82. https:// doi.org/10.21043/thufula.v2i1.4266

Tan, E. (2013). Informal learning on YouTube: Exploring digital literacy in independent online learning. Learning, Media and Technology, 38(4), 463-477. https:// doi.org/10.1080/17439884.2013.783594

Umar, M. (2020). Peranan Orang Tua Dalam Meningkatkan Prestasi Belajar Anak. Musawa: Journal for Gender Studies, 12(1), 108-139. https:// doi.org/10.24239/msw.v12i1.591

Zeng, N., Ayyub, M., Sun, H., Wen, X., Xiang, P., \& Gao, Z. (2017). Effects of Physical Activity on Motor Skills and Cognitive Development in Early Childhood: A Systematic Review. BioMed Research International, 2017, 1-13. https://doi.org/10.1155/2017/2760716 